Review

\title{
Goat grazing, its interactions with other herbivores and biodiversity conservation issues
}

\author{
R. Rosa García*, R. Celaya, U. García, K. Osoro \\ SERIDA - Servicio Regional de Investigación y Desarrollo Agroalimentario, P.O. Box 13, 33300 Villaviciosa, Asturias, Spain
}

\section{A R T I C L E I N F O}

\section{Article history:}

Received 28 November 2011

Received in revised form 27 March 2012

Accepted 28 March 2012

Available online 21 April 2012

\section{Keywords:}

Biodiversity

Conservation

Environment

Goats

Grazing

Management

\begin{abstract}
A B S T R A C T
Goats have developed in harmony with local conditions of climate, terrain, vegetation, and even pathogens over centuries in many areas, while they have been blamed of causing environment degradation in other ones. The paper summarizes the situation of goat's population worldwide, the status of the breeds and the multiple implications of their conservation, the interactions of goats with other animal species (wild or domestic) and the main issues regarding the consequences of goat grazing from the environmental point of view. It underlines that most of the environmentally harmful effects of goat grazing arise from improper management practices at very high grazing pressures whereas goat grazing can be a useful tool for conservation if managed adequately. Moderate grazing pressures can be compatible with high levels of biodiversity and provide externalities, whereas high intensity at short term can be a valuable tool for weed control. Goat genetic heritage is seriously threatened and requires more studies and greater support from national and international institutions, in parallel with other efforts in rural development, especially for remote areas which hold an outstanding reservoir of livestock diversity adapted to the local conditions and managed by impoverished communities. A multidisciplinary approach of scientists, policy makers, rangeland managers and local communities is required for the design of future sustainable management plans.
\end{abstract}

(c) 2012 Elsevier B.V. All rights reserved.

\section{Introduction: past, present and future of world goat populations}

Goats are among the first ruminants to be domesticated and possibly the second species to be taken into the human fold after the dog (Wilson, 1991). Domestication started with the bezoar (Capra aegagrus (Erxleben, 1777)) in southwest Asia (Iran and Iraq) about 10,000 years ago (Mason, 1984).

The global census of this ruminant was around 920 million heads in 2010 (Table 1). Despite their global distribution, they are more abundant in the developing countries (about $98 \%$ of the total population) and around the tropics

\footnotetext{
* Corresponding author. Tel.: +34 985890066; fax: +34 985891854 E-mail address: rocior@serida.org (R. Rosa García).
}

and dry zones (Devendra, 2010), especially in Asia (60\%) and Africa (33.8\%). Within Asia, the greatest concentrations occur in China, India and Pakistan (39.6\% of the world goat population and $66 \%$ of the continent). The rest are found mainly in Latin America, the Caribbean, Europe and Caucasus. Within the European Union (EU), around 12 million goats were recorded during 2010 and they were mostly reared in Greece (33.6\%), Spain (23.5\%), France (10.8\%) and Italy $(7.7 \%)$ (Table 1$)$.

The world goat population growth has been constant (2.6\% annual growth rate over the period 1986-2007 and $2.8 \%$ considering solely developing countries) whereas the opposite pattern is observed in Europe (Devendra, 2010; Table 1). The global increase is expected to continue (Rosegrant et al., 2009) regardless of the rapid global shift towards a monogastric livestock production which has expanded more than fourfold over the past decades (Steinfeld et al., 2006). 
Table 1

Stocks (heads) of goats in different regions and countries of the world.

\begin{tabular}{|c|c|c|c|c|c|c|}
\hline Region/country & 2000 & 2002 & 2004 & 2006 & 2008 & 2010 \\
\hline European Union & $14,443,626$ & $13,636,224$ & $13,993,375$ & $13,775,641$ & $13,791,939$ & $12,487,721$ \\
\hline France & $1,210,520$ & $1,231,560$ & $1,240,000$ & $1,232,640$ & $1,283,120$ & $1,349,030$ \\
\hline Greece & $5,614,450$ & $5,180,000$ & $5,619,100$ & $5,422,240$ & $5,345,620$ & $4,200,000$ \\
\hline Italy & $1,397,000$ & $1,025,000$ & 960,994 & 945,000 & 920,000 & 961,000 \\
\hline Spain & $2,627,000$ & $3,046,720$ & $2,833,220$ & $2,956,730$ & $2,959,300$ & $2,933,800$ \\
\hline Africa & $234,220,237$ & $250,890,414$ & $267,685,212$ & $279,276,912$ & $299,259,339$ & $310,718,293$ \\
\hline America & $34,938,153$ & $36,187,103$ & $37,056,339$ & $38,013,119$ & $37,411,782$ & $37,211,489$ \\
\hline Asia & $458,521,301$ & $463,392,884$ & $486,798,255$ & $504,422,915$ & $529,504,472$ & $551,227,448$ \\
\hline China & $148,478,245$ & $145,872,929$ & $149,928,862$ & $146,858,033$ & $143,595,223$ & $150,708,101$ \\
\hline India & $123,533,000$ & $124,077,000$ & $128,213,000$ & $136,286,000$ & $145,000,000$ & $154,000,000$ \\
\hline Pakistan & $47,426,000$ & $50,917,000$ & $54,679,000$ & $53,789,000$ & $56,742,000$ & $59,900,000$ \\
\hline World & $749,030,481$ & $771,903,084$ & $813,546,950$ & $843,935,961$ & $887,709,227$ & $920,608,951$ \\
\hline
\end{tabular}

Source: FAOSTAT.

\section{Goat breeds}

The diversity of goat breeds is remarkable (they represent $12 \%$ of all the breeds within the mammals) and includes 543 local, 46 regional transboundary and 38 international transboundary breeds (FAO, 2010b). Such diversity is a result of both natural selection for fitness under varied conditions and artificial selection practised by breeders. The Saanen is the world's most widespread breed and, together with the Anglo-Nubienne, Boer, Toggenburg, Alpine, West African Dwarf, Angora and Creole, they are present in more than 24 countries (FAO, 2010a). The majority of the breeds (76\%) are reared in the developing countries, mostly in Asia and Africa (42\%), while another 195 local breeds occur in Europe and the Caucasus, mainly around the Mediterranean area (170 breeds) (Devendra, 2010; FAO, 2010a,b).

The flourishing of intensive livestock production systems which utilize a narrow range of breeds has contributed to the degradation of the animal genetic resources and the marginalization of the traditional livestock production ones, leading many breeds to a risk of disappearance (FAO, 2009). So far, the greatest loss of genetic resources occurs in Europe (16 out of the 19 extinct goat breeds worldwide) although, according to the European farm animal biodiversity information system (FABISnet), the status of endangerment of $86.5 \%$ of the breeds is unknown there, due to the lack of enough data to estimate it, although five European breeds are "endangered" and 13 are "critical" (Duchev et al., 2006). Notwithstanding the status of the breeds is even more poorly documented in Asia or Africa, where many of the more rarely used and best-adapted animals are found, and where many breeds face the danger of genetic erosion. Such lack of data leads to an incomplete and distorted picture of the status and trends of domestic animal breeds worldwide (Shand, 1997). Furthermore, the survival of autochthonous breeds can be associated with the survival of indigenous ethnic groups, frequently pastoralist, which are pushed, together with their livestock, to marginal areas. These trends occur in remote areas of China and India located in border states and provinces with harsh terrain and great breeds-to-people ratios (Hall and Ruane, 1993).

The FAO has a 50-year record of promoting research into livestock diversity and of advocating its conservation (FAO, 2010a,b), but there are few internationally or nationally funded projects, even within the richer nations (Hall, 2004). The Interlaken Declaration on Animal Genetic Resources already recognized the existence of serious gaps and weaknesses at national and international level which prevented an efficient inventory, monitorization and characterization of the animal genetic resources, hindering their sustainable use and conservation, and financial resources and long-term support at national and international level were urgently demanded (FAO, 2007).

We do not observe a much greater progress nowadays and the current government policies are sometimes contradictory. For example, the latest reform of the EU Common Agricultural Policy (CAP), despite including initiatives to arrest the loss of genetic resources, is expected to accelerate goat farming abandonment, and especially of those working with indigenous stock, as the decoupling process progresses (Canali, 2006; Castel et al., 2010). Therefore, we must continue stressing that the survival of the valuable genetic biodiversity would lay on the international support from institutions like FAO, on the improvement of national and international government policies, and in the case of Europe, on the efforts of the national associations related to the maintenance or establishment of goat flock books, such as the existing 19 Spanish associations, which carry on active conservation or breeding programs (e.g. Camacho Vallejo et al., 2005; Figueroa et al., 2003; Gómez et al., 1998). There is evidence of how coordinated efforts from different institutions can contribute to the conservation of endangered breeds. Once the Spanish Official Catalogue of Livestock Breeds highlighted the urgency of conservation efforts to preserve the Pitüsa or Ibicenca goat breed, endemic from two of Balearic Islands and, under evident risk of extinction, the association of producers of this breed, together with the Balearic Institute of Animal Biology and the University of Córdoba carried out an efficient rescue program following FAO's technical recommendations (Camacho et al., 2011). Apart from saving the valuable genetic heritage, a parallel plan searches for attributes that enhance its economical value to promote its expansion.

The local breeds are claimed to be superior with regard to the use of marginal lands and where feed resources are limited. That is the case of most of the indigenous breeds of semi-arid and arid areas, which utilize feed of high-fibre and low-quality content more efficiently than the exotic 
ones (Silanikove et al., 1993). However, in some circumstances exotic breeds can adapt to the conditions in other areas. Cashmere goats endured the low nutritive quality of the vegetation in Cantabrian heathlands ( $N$ Spain) better than the Celtiberic local breed (Osoro et al., 2007), possibly owing to the different grazing behaviour, smaller body size and lower total maintenance requirements of the former (Silanikove, 2000). Regarding their effects on the biodiversity, the floristic richness tended to be higher in areas grazed by the locals although, after four years, evenness index dropped there due to the dominance of certain grass species (Celaya et al., 2010), while the arthropod assemblages did not differ between breeds (Jauregui et al., 2008; Rosa García et al., 2009a,b). Nevertheless, the knowledge about the effects of the different breeds on the local biodiversity should be clearly improved.

\section{Interaction of goats with other livestock species}

The coexistence of goats with other livestock species has been controversial as they might compete for the forage resources, while they are complementary with others, depending on multiple factors like the stocking densities, grazing behaviour of each species, vegetation, year, and season (Bartolomé, 1994; Cuartas, 1992; Rook et al., 2004; Shrestha et al., 2005). The controversy increases when they become the last available species to farmers ("the cows of the poor") and they get involved in a vicious circle. Many of the world's deteriorated rangelands were firstly damaged by cattle and sheep overgrazing, so the pasturage left (browse or shrubs) could be used only by goats (Huss, 1972). They are also the last species that impoverished farmers can keep when they cannot afford the bigger and more demanding large herbivores, so they incorporate higher proportions of goats in their mixed flocks. Free ranging indigenous goat breeds on highly degraded grazing lands in semi-arid areas can be 2.5 times more economical than indigenous sheep (Swain, 1984). In sub-Saharan Africa, population pressure and land fragmentation forced small farms to turn to small ruminants, and particularly goats, as they were unable to support cattle, and in northern Kenya and southern Ethiopia, pastoralists claim that invasion by woody species drove them to increasingly substitute their cattle for camels and goats (Peacok and Sherman, 2010). In other cases, a switch from cattle to small ruminants occurs in arid-semiarid rangelands of East and West Africa in times of drought, when forage is scarce (Nyong et al., 2007). Therefore, rather than being drivers of desertification, goats are actually one of the most adaptable large herbivorous species to marginal mountainous or desert areas (Silanikove, 2000). It must also be stated that some of the best pastoral lands (in terms of soils and rainfall) which were converted into crop production, despite being frequently unsuitable for that activity, were later recovered by pastoralists in a much less productive state (Sidahmed, 1986). Therefore, in many cases, goats "inherit" an already "desolate" landscape which can be further depleted if not properly managed.

From another perspective, beneficial effects of goat grazing for other domestic herbivores have been observed. In improved pastures, the presence of white clover
(Trifolium repens) is enhanced when goats are present in the herd compared with single grazing by sheep while grass flowering stems are more consumed by goat, leading to greater percentages of green leaves in the sward. This pattern has been observed in Great Britain (del Pozo et al., 1996; Grant et al., 1984; Penning et al., 1996), Spain (Celaya et al., 2007; del Pozo et al., 1998) or New Zealand (Clark et al., 1984). These botanical and structural changes imply a higher nutritive quality of the available pasture, resulting in higher livestock performances under integrated mixed, rotational or sequential management with goats, for both sheep (Radcliffe et al., 1991; del Pozo et al., 1996, 1998) and cattle (Osoro et al., 2000). Other benefits of mixed grazing are known from semi-arid rangelands, where it might enable to decrease from 26 ha per tropical livestock unit (a TLU is equivalent to $250 \mathrm{~kg}$ live weight) for cattle alone to $13 \mathrm{ha} / \mathrm{TLU}$ when cattle and goats are reared together (Schwartz, 1983).

Regarding the impact on the local fauna, sheep and goats associated to similar arthropod assemblages in heather dominated areas in Cantabrian heathlands, but to different assemblages in herbaceous dominated areas, where goats enhanced herb growth while decreased shrub cover and provided more favourable conditions for certain arthropod species (Rosa García et al., 2010b). In nearby partially improved heathlands, the diversity of arthropods was higher in paddocks grazed by mixed herds of either sheep or cattle with goats than in others under monospecific grazing of cattle or sheep, especially within the shrubland areas. The local fauna benefited from the greater vegetation structural complexity resulting from the goat's browser behaviour (Rosa García et al., 2010a, 2011).

Therefore, a profound knowledge of livestock grazing behaviour and diet selection is necessary to understand their impact on biodiversity and it can represent an interesting environmental tool.

\section{Interaction of goats with wild herbivores}

The relationship between livestock and native herbivores is linked to conflicts between farmers, conservationists, hunting game managers, etc., and it greatly depends on their competition for the resources. Excessive or inappropriate goat grazing has posed a threat to some native herbivores worldwide (Dawson and Ellis, 1994), while they appear complementary with others (Dawson and Ellis, 1996; Mishra et al., 2001). So far, conclusions on the impact of livestock on native ungulates are heterogeneous and highly debated, especially regarding the processes and the outcome of the interactions (e.g. Madhusudan, 2004; Mishra and Rawat, 1998; Young et al., 2005).

The competition for forage between the wild ass named kiang (Equus kiang Moorcroft, 1841) and livestock generates conflicts with pastoral communities in the Indian Trans-Himalaya which are linked to the loss of pastures during the Indo-Chinese war in 1962 or the increase of the cashmere production there (Bhatnagar et al., 2006).

The spatial expansion and population recovery of the tahr (Hemitragus jemlahicus (C.H. Smith, 1826)), and its minimal spatial overlap with the migratory herds of sheep and goats in the Himalayan Kedarnath Wildlife Sanctuary 
are related to the decrease of livestock numbers, although there is a concern about its situation in nearby areas with heavy livestock grazing and poaching of tahr (Kittur et al., 2010).

The Tibetan argali (Ovis ammon hodgsonii Blyth, 1841) either had a separated diet selection and habitat use from domestic goats in Nepal (Shrestha et al., 2005) or overlapped in Mongolian protected areas. The livestock-argali conflicts are associated with the flourish of the cashmere fibre production, the increase in livestock numbers, herding families and improper management (Reading et al., 2006), so the reduction of both people and livestock, antipoaching activities or controlled sport hunting is suggested to arrest its decline (Reading et al., 1997). In Western China, this species is threatened by gold mining activities, the construction of an aqueduct or its dietary overlap with livestock (Harris and Pletscher, 2002).

The growth of cashmere production also threatens the endangered Tibetan gazelle (Procapra picticaudata Hodgson, 1846) in the Indian Trans-Himalaya (Namgail et al., 2007, 2009). Despite its similar diet to sheep and goats in Mongolia, competition could not be inferred, but serious habitat deterioration was caused by policies which promoted a shift from a nomadic to a sedentary society (Campos-Arceiz et al., 2004).

The Himalayan blue sheep, bharal or naur (Pseudois nayaur (Hodgson, 1833)) overlaps its diet with goats in the Indian Trans-Himalaya (Mishra et al., 2001, 2004), whereas it is more abundant in neighbouring areas with lower livestock stocking rates (Mishra et al., 2002). It either spatially overlapped with livestock in Tibet (Schaller and $\mathrm{Gu}, 1994$ ), or had both diet and habitat separation in this region and Nepal (Harris and Miller, 1995; Shrestha et al., 2005). Shah (2003) linked its decline in Nepal to hunting activities, diseases transmitted by livestock and genetic or environmental mishaps, coupled with predation by wild carnivores. The resource use overlap between naur and goats occurs mostly in spring and summer, when domestic stock is seasonally rotated among different pastures, a system which might also facilitate their coexistence through resource partitioning (Shrestha and Wegge, 2008). The naur uses a similar habitat type to yak (Bos grunniens Linnaeus, 1766) (Harris and Miller, 1995; Shrestha and Wegge, 2008) and Himalayan ibex (Capra sibirica hemalayanus, Hodgson, 1841) (Bagchi et al., 2004).

The Himalayan ibex deals with resource limitations imposed by migratory herds of goats and sheep around the Indian Trans-Himalayan pastures, while it is unaffected by the resident livestock as most species show habitat separation (Bagchi et al., 2004; Bhatnagar, 1997). The feeding habits and forage preferences of the Iberian ibex (Capra pyrenaica Schinz, 1838) are closer to feral goats (Capra hircus (Linnaeus, 1758)) than to domestic ones in Mediterranean mountain scrublands (Aldezabal and Garin, 2000). In the Cazorla Mountain Range (south Spain), while goats consumed mostly evergreen oak (Quercus ilex L.), ibex selected a mixed diet of ligneous plants, graminoids and herbaceous plants (García-González and Cuartas, 1989). Cuartas (1992) confirmed the low index of similarity in their diets, although the lowest overlap occurred between domestic goats and mouflon (Ovis musimon Pallas, 1762).
Goats coexist with chamois (Rupicapra rupicapra Linnaeus, 1758 ) in northern Spain, where they both have different diet selection and low similarity index (27.2\%) (Aldezabal, 2001).

Although goats appeared to have negative affects on Ibex in Castilla-La Mancha (Spain) by displacing it from its optimal habitat (Acevedo et al., 2007), the ibex populations were in expansion there and coexisted with other wild ungulates such as wild boar (Sus scrofa Linnaeus, 1758), red deer (Cervus elaphus Linnaeus, 1758), fallow deer (Dama dama Linnaeus, 1758), and roe deer (Capreolus capreolus Linnaeus, 1758). Later on, red deer translocations for sport hunting were also claimed to impose a threat on ibex in mountainous regions of southern Spain (Acevedo and Cassinello, 2009).

In the Isle of Rhum (Scotland), red deer selected mesotrophic communities while free-ranging goats preferred others dominated by dwarf shrubs (Gordon, 1989). Fraser and Gordon (1997) indicated that the differences in diet composition between red deer and goats grazing on different vegetation types in Scotland could be of interest to develop management protocols for vegetation communities of high nature conservation value.

White-tailed deer (Odocoileus virginianus (Zimmermann, 1780)) and goats responded differently to the distribution of browse plants in a Texas shallow ridge range site, with goats being more influenced by overall plant community structure whereas white-tailed deer were more affected by the distribution of their preferred forage species (Etzenhouser et al., 1998). Under rangeland conditions in Texas (USA), this deer was favoured by controlled grazing with sheep and goats, although their stocking should be carefully managed during the critical times of the year (winter, early spring) when competition might affect deer negatively (Bryant et al., 1979).

In the African savanna, goat's diet may overlap with dik-dik (Madoqua sp.), kudu (Tragelaphus strepsiceros (Pallas, 1766)), eland (Taurotragus oryx (Pallas, 1766)), impala (Aepyceros melampus (Lichtenstein, 1812)), black rhinoceros (Diceros bicornis (Linnaeus, 1758)), or giraffe (Giraffa camelopardalis (Linnaeus, 1758)) (Prins, 2000; Breebaart et al., 2002). Goats control shrub encroachment (particularly of Acacia species) less efficiently than dik-dik (Augustine and McNaughton, 2004) and eat more grasses than kudu and gazelle, but less than impala (Owen-Smith and Cooper, 1985; Hoppe et al., 1977). While foraging at similar height as eland (although they generally consume different species), goats do it at different one to giraffe (Breebaart et al., 2002).

The inconsistent pattern among different studies might relay on local adaptations of the ungulates within their geographical ranges and the changes in the phenology, and hence quality, of forage plants between areas (Shrestha et al., 2005).

The presence of humans may obscure natural interactions between wild and domestic ungulates, acts as a displacement factor and can reduce their habitat overlap as it influences the foraging behaviour of wild ungulates (Namgail et al., 2007), so it might be considered in addition to exploitative competition patterns (Bagchi et al., 2004; Harris and Loggers, 2004). The presence of both small 
ruminants (mainly sheep) and people contributed to reduce the distribution area for chamois in northern Spain, forcing them to move (Aldezabal, 2001), although a vertical natural migration of chamois is already known (Pérez Barbería, 1994) and it is greatly influenced by the cover and the depth of the snow (Garcia-Gonzalez et al., 1990). Mongolian gazelles (Procapra gutturosa (Pallas, 1777)) had a consistent feed composition among different areas while sheep and goat varied, maybe mediated by herding management, which turned important for the conservation of the wild ungulate (Yoshihara et al., 2008). Furthermore, the human-adapted strategy of seasonally rotating domestic herds across different areas to optimize the use of limited feed resources might have facilitated their coexistence with naur through partitioning of resources (Shrestha and Wegge, 2008).

The situation of livestock vs. wild ungulates regarding nature conservation in the Mediterranean landscapes has evolved since the 1960s. Whereas livestock numbers are declining, wild ungulate populations have increased as a result of rural abandonment, the expansion of protected areas and the outstanding growth of big game hunting demand. For example, the annual Spanish harvest of wild boar has increased by tenfold during the last 35 years (Bueno et al., 2009) and red deer numbers have also grown at an exponential scale (Milner et al., 2006).

Wild ungulates might assume part of the traditional contribution of livestock to rural development and to the conservation of cultural landscapes and insect fauna (Theuerkauf and Rouys, 2006), but they also require an adequate management, especially of those species of hunting interest like wild boar or red deer, whose overexpansion is already generating conflicts with the local communities, threatening the environment and increasing herbivory pressure, and even affecting negatively other wild species such as Iberian ibex in certain areas (Acevedo and Cassinello, 2009; Bueno et al., 2009). According to Zamora et al. (2001) and Gómez et al. (2003), the conservation and restoration of forests of most Mediterranean mountains require the proper management of both wild and domestic ungulates.

\section{Goat grazing and habitat conservation}

Goats are defined 'the black sheep' among livestock by consuming almost everything edible and they have been blamed for causing habitat degradation (Peacok and Sherman, 2010). Feral goats are considered a pest in semiarid rangelands in Australia (Parkes et al., 1996), where their commercial harvest is suggested as an economic opportunity, but also as a tool to minimize their negative impacts on both agricultural production and native species and habitats (Choquenot et al., 1998). Goats have been eradicated from at least 120 islands worldwide (Campbell and Donlan, 2005) where their introduction has frequently resulted in ecosystem degradation and biodiversity loss (Coblentz, 1978; Schofield, 1989). Within the Aldraba Island (Seychelles), a World Heritage site, their eradication started once their numbers increased and prompted concern for the future of the local biota (Coblenz et al., 1990). The intense goat grazing in various Galapagos Islands affected the native vegetation severely over many decades (Hamann, 1979) and the posterior population control programs seemed to contribute to the recovery of birds like rails (Laterallus sp.) (Donlan et al., 2007). Although invertebrate diversity increased in Volcán Alcedo (Galápagos) after a severe grazing by introduced feral goats which temporarily increased habitat heterogeneity, its conservation value was questioned, and the species naturally occurring in the scrub and groves, as well as others from humid open habitats, were expected to disappear unless the situation was reversed (Desender et al., 1999). Conversely, moderate goat grazing is considered valuable for the conservation of pastures dominated by native or endemic species in Tenerife Island (Fernández-Lugo et al., 2009), and negative effects on plant diversity are expected after goat grazing abandonment in pastures which sustain endemic plant species in La Gomera Island (Arévalo et al., 2011).

Most of the abovementioned examples highlight that it might not be goats per se that is the real culprit, but their mismanagement, frequently by overgrazing. Furthermore, goats having a potential positive impact on vegetation regeneration and biodiversity improvement ( $\mathrm{El}$ Aich and Waterhouse, 1999), they have returned to several unmanaged grasslands around Europe with aims of conservation of the biodiversity (Ferrer et al., 2001; Muller, 2002). They can also contribute to preserve ecosystems like heather, moor, marsh wet meadow and other unique biotops present in protected areas (Martyniuk and Olech, 1997).

Within calcareous grasslands in the Franconian Jura, small ruminant grazing periods are adjusted to the life cycle of the butterfly Parnassius apollo (Linnaeus, 1758). Its conservation has been enhanced by including goats into the sheep herds to allow new growth of Sedum album, the feed-plant it requires (Dolek and Geyer, 2002). Grazing by small ruminants in these areas becomes a central option for long-term conservation, once the timing, intensity and spatial distribution are planned, and the infrastructure and social conditions required by the herders to keep grazing practicable are provided (Dolek and Geyer, 2002). Traditional rough grazing with sheep and goats was also the most favourable tool for the preservation of the Duke of Burgundy butterfly (Hamearis lucina, 1758) in German calcareous grasslands (Fatmann, 2006). Balanced management of goat, sheep and rabbit populations is also among the prescriptions to preserve the shrubland habitat needed for the survival of the butterfly Plebejus argus (Linnaeus, 1758) in north Wales (Dennis, 2004).

Within Los Filabres area in SE Spain, a retrospective analysis revealed that the abandonment of cereal mountainous practices and the posterior development of goat grazing practices, far from leading to the degradation of the area, contributed to the restoration of the plant canopy, revealing that the comparison of grazing with degradation should be questioned (Robles et al., 1997).

Goat production and management in agro-forestry systems are also related to habitat conservation. The very complex, species-rich and traditionally managed homegardens are sustainable agro-forestry systems, frequently include goat grazing, and are considered neglected hotspots of agro-biodiversity and cultural diversity (Galluzzi et al., 
2010). The silvopastoral systems are another agro-forestry combination where woody fodder species can be key sources of nutrients for livestock (e.g. Papachristou and Papanastasis, 1994; Rigueiro-Rodríguez et al., 2005). Goat grazing can benefit the production of trees (oil palms, rubber trees, coffee, etc.), but also carbon sequestration (Ørskov, 2011) because goats can help to restore the cycling of plant nutrients sequestered by woody species, as observed in Black Kettle National Grassland (Oklahoma), where available N, P and K increased on the soil after three years of goat grazing of shinnery oak (Quercus havardii Rydb.)(Hart, 2001). It can also improve soil fertility through nutrient recycling and $C$ sequestration after long term goat grazing, without additional soil management practices, in loblolly pine-goat (Pinus tadea L.) silvopastures in Southeast USA, making the system both environmentally and economically sustainable (Nyakatawa et al., in press).

The Dehesa (in Spanish) or montado (in Portuguese) is a traditional Mediterranean silvopastoral system which has evolved under extensive mixed livestock grazing (including goats) and supports an extraordinary biodiversity, including highly endangered species such as the Iberian lynx (Lynx pardinus (Temminck, 1827)), the imperial eagle (Aquila adalberti Brehm, 1861) or the cinereous vulture (Aegypius monachus (Linnaeus, 1766)). The conservation programs of these species require management practices which preserve their habitat and provide the resources (e.g. rabbits) they need (González and San Miguel, 2004).

As it will be explained further on in this manuscript, silvopastoral methods which include goats are also a powerful tool for habitat conservation through the prevention of fire risks by an efficient control of the accumulation of flammable woody vegetation (Etienne et al., 1996; Jáuregui et al., 2009; Rigueiro-Rodríguez et al., 2005).

\section{Bush encroachment and fire risk reductions}

The bush encroachment is caused by various factors, including fire frequency, under-utilization of the bushes and overgrazing of herbaceous vegetation (Smit et al., 1999). According to the FAO, fires affect an estimated 350 million hectares of land worldwide every year and cause losses of lives, enormous ecological and economic damage in forests and agriculture areas and contribute to global warming, air pollution, desertification and loss of biodiversity.

Among ruminants, goats are able to reduce bush cover more efficiently than sheep or cattle (Sineiro, 1982; Benavides et al., 2009). They reduced it from 45 to $15 \%$ in one year on hill pastures of the Appalachians, whereas sheep required 3 years to bring the same results (Magadlela et al., 1995). Although Fajemisin et al. (1996) questioned the potential of Spanish goats for woody plant control in good condition sagebrush steppe pastures, other authors reported that they were more willing to eat browse than Angora goats (Pritz et al., 1997; Warren et al., 1984), or that they reduce it more than Cashmere ones (Celaya et al., 2010). In Cantabrian heathlands, gorse (Ulex gallii) biomass was more efficiently controlled with goat than with sheep grazing, favouring herbaceous presence and turning goats a valuable tool to reduce fire risk (Benavides et al., 2009; Celaya et al., 2007; Jáuregui et al., 2009).

In the Sacramento River and Stone Lakes National Wildlife Refuges (northern California), goats are also used to reduce overgrown vegetation in areas at risk of wildfire and maintain the critical habitat for migratory birds along the Pacific Flyway (see http://www.fws.gov/fire/news/ca/goats.shtml). In New Hampshire they are used by an electric company to clear under the powerline in an ecologically friendly manner (Hart, 2001). They have also been utilized to control the highly flammable shrubs of the southern California chaparral (Green and Newell, 1982; Sidahmed et al., 1981), they assisted in controlling bush encroachment in savannas (Mahanjana and Cronje, 2000; Ward, 2005), in woody plant control in Tanzania's Massailand (Martin and Huss, 1981) or in western Texas (Ueckert, 1980). They also contributed in reducing Gambel oak (Quercus gambielii) sprouts in Colorado (Davis et al., 1975) and in biological control efforts in Australia and New Zealand (Gray, 1984; Holmst, 1980; Radcliffe, 1985). The woody encroachment of previously cultivated areas of the pre-Alps mountains (SE France) and Corsica increased fire risk considerably and concerns about whether the remaining animal husbandry can make a sustainable use of the natural ligneous plants rose. The Livestock Farming Systems (LFS) research programs carried out by the INRA explored the capacity of adapting small ruminant grazing management for preventing fire risk (Flamant et al., 1999). Such capacity is confirmed in Spain, where goats have been successfully managed for controlling bushes with high ignition capacity (Valderrábano and Torrano, 2000) and clearing fuel breaks (Martín et al., 2011), while contributing to integrate livestock breeders in sustainable initiatives (Ruiz Mirazo et al., 2009).

Finally, the environmental concerns and the economic costs of chemical and mechanical methods for clearing and maintaining firebreaks provide an opportunity to utilize biological control methods such as goats for these purposes (Green and Newell, 1982; Launchbaugh, 2006). In the case of mechanical methods, it provides an alternative in remote areas or with steep slopes, and it would also contribute to reduce the use of fuel and therefore, the environmental pollution.

\section{Use of crop residues and crop by-products}

The use of crop wastes as feed facilitates the return of nutrients to the soil via the production of manure and urine, which, carefully managed can result in improved soil fertility and structure, and higher humus levels, thereby increasing crop production (FAO, 2009). Although sometimes relatively indigestible for goats, plant residues from vegetable crops, tuberous crops, green stover of corn, sorghum and millet can be excellent feeds when fed green. They have been traditionally used by nomads or transhumant pastoralists during the dry period but, as these activities are ceasing, further research is needed to integrate pastoralism with cropping, conservation and forage production, especially during that period (Wilson, 1991). 
Some crop by-products such as rice or wheat bran, cassava chips, peanut, sunflower or linseed cake and sugar-cane tops have also been used as low-cost feed supplements for goats (Peacok, 1996). Their utilization during summer, when perennial forage plants are less available, could contribute to easing grazing pressure on vegetation and reduce its degradation, as reported from the Tehuacán-Cuicatlán Valley in Mexico (Baraza et al., 2010) or the northern mountainous areas of Oman (Schlecht et al., 2009).

\section{Weed control}

The impacts of noxious weed invasion include loss of biodiversity (Tyser and Key, 1988), increased soil erosion (Lacey et al., 1989), loss of wildlife habitat (Wallace et al., 1992) or reductions of the carrying capacity for domestic livestock (Hein and Miller, 1992). The role of goats as biological control agents is becoming more important due to environmental concerns and elevated costs of other control methods such as mechanical cutting or herbicide application (Magadlela et al., 1995), as already mentioned for firebreaks. According to Launchbaugh (2006), the problem with invasive weeds in the Western USA resulted from declining small ruminant numbers during the past 20 years, as many of the worst weeds, like leafy spurge (Euphorbia esula), yellow starthistle (Centaurea solstitialis) and spotted knapweed (Centaurea maculosa) are palatable and nutritious for them. The goat eradication in Round Island (Mauritius), Carnac Island (Australia) and Channel Islands (USA) also led to long-term increasing influence by undesirable exotic plants (Abbott et al., 2000; Bullock et al., 2002; Halvorson et al., 1988). The suitability of goats for weed control involves numerous species (Table 2). They are useful to maintain pastures through the control of dock (Rumex obtusifolius) in Japan (Sakanoue et al., 1995), gorse (Ulex europaeus or Ulex gallii) in New Zealand (Radcliffe, 1985), Tasmanian midlands (Harradine and Jones, 1985) or Spain (Sineiro, 1982; Celaya et al., 2007), soft rush (Juncus effusus) in Great Britain (Merchant, 1993), spotted knapweed (Williams and Prather, 2006) and yellow starthistle (Goehring et al., 2010) in Idaho, or for general bush clearing in Texas (Merrill and Taylor, 1981) and California (Adams and Hughes, 1977). They have also been used to control invasive woody plants such as juniper (Juniperus sp.) and mesquite (Prosopis glandulosa) on rangelands in SW USA (Brock, 1988; Hanselka and Paschal, 1992) and to renovate pastures dominated by herbaceous weeds, brush and multiflora rose bushes imported from Japan in the Appalachian region (Luginbuhl et al., 1999). Together with acetic acid (vinager), goat grazing seemed as cost effective as single application herbicides to control certain weed species while posing fewer concerns over impacts on human and ecosystem health in northern Canadian communities (Booth and Skelton, 2009). Compared to other livestock species, goats control spiny or poisonous brush weeds like gorse or poison ivy (Toxicodendron radicans) better than sheep or cattle (Popay and Field, 1996; Celaya et al., 2007). They also control leafy spurge (Lym et al., 1997) better than the other livestock species and, because of their lower dietary overlap with cattle, they might be preferred by cattle rangers over sheep for their mixed herds to reduce the weed enough to allow cattle grazing (Lym, 1998; Olsen and Hansen, 1977). In perennial pastures infested with nodding thistle (Carduus nutans), goats selectively consumed thistle capitula throughout the flowering period and controlled its spread (Holst et al., 2004). All these works on weed control by goat grazing reveal their potential for mixed grazing with other herbivores due to the high complementary on different pastures.

\section{Seed dispersers}

Livestock appears to be one of the primary vectors of seed dispersal with positive or negative consequences attending to several factors. In the case of goats, the rate of passage and viability of the noxious weed seeds they consume are low (Launchbaugh, 2006). They also preferentially consume seeds in an immature stage and prefer seedling stems, reducing the spread and perpetuation of weeds by seed (Hart, 2001). Goats appear to be poor dispersers of invasive plants such as mesquite, but also of non-invasive ones, as it occurs with different fodder grasses in Mongolian rangelands (Bläß et al., 2010). On the contrary, they acted as efficient seed dispersers of diverse plant species in the Biosphere Reserve of the Tehuacán-Cuicatlán Valley (Baraza and Valiente-Banuet, 2008) but also of certain leguminous shrubs native of the Mediterranean Basin which are considered useful plants for recovering degraded shrublands (Robles et al., 2005). Mancilla-Leytón et al. (2011) observed that the number of seeds retrieved by goats differed between the four common Mediterranean shrub species they were fed with, and it should be taken into account for the design of future management plans which aim either to prevent shrub invasion of undesired plants, or to spread populations of desirable shrub species.

\section{Landscape conservation}

In many regions the evolution of landscapes has been intimately related with animal activity, and landscape management addresses various situations where grazing animals may provide services to the environment. It includes grazing "social fallows" and any other uncultivated or waste lands in order to control succession and to provide easy access for the public for recreation and leisure. The restoration of traditional landscapes like permanent pastures in Haut-Verdon, France (Decaix, 1994), or rural landscapes in Extremadura, Spain (Blázquez et al., 1995; Gallego et al., 1995) was successfully done through the use of small ruminants, which contribute with their grazing besides being a part of the local culture, providing entertainment and special animal products for tourists. Nevertheless, the promotion of extensification and fallowing in western European countries as a consequence of EU policy has resulted in increasing areas of uncultivated land which threaten the maintenance of the landscape if proper national/regional policies are not adopted (Martyniuk and Olech, 1997). 
Table 2

Summary of plant species considered weeds and which are palatable to goats.

\section{Scientific name \\ Acacia aneura \\ Acacia escelsa \\ Acacia farnesiana \\ Acacia karoo \\ Acacia mearnsii \\ Acacia nilotica \\ Acacia homalophylla \\ Acacia paradoxa \\ Acaena ovina \\ Acetosa sagittata \\ Acroptilon repens \\ Aesculus spp. \\ Agapanthus spp. \\ Agave spp.}

Agerantina adenophora

Ageratum houstonianum

Ageratum riparia

Agrostis avenaced

Ailanthus altissima

Alhagi pseudalhagi

Allium triquetrum

Allium vineale

Alternanthera pungens

Amaranthus spp.

Amaryllis belladonna

Ambrosia artemisiifolia

Ambrosia confertiflora

Ambrosia psilostachya

Ambrosia tenuifolia

Ammi majus

Amsinckia spp.

Andropogon virginicus

Angophora spp.

Anredera cordifolia

Amthemiscotula

Apophyllum anomalum

Araujia hortorum

Arctotheca calendula

Aristida spp.

Atalaya hemiglauca

Atriplex spp.

Avena spp.

Baccharis halimifolia

Bambusa spp.

Bidens spp.

Brachychiton populneus

Brassica tourneforti

Bromus diandrus

Bromus tectorum

Bryophyllum spp.

Bursaria spinosa

Buxus spp.

Calandrina spp.

Calicotome spinosa

Callitris columellaris

Callitris endlicheri

Calotropis procera

Caninia quinquefaria

Cannabis sativa

Capparis mitchellii

Capsella bursa-pastoris

Cardaria draba

Cardiospermum spp.

Carduus nutans

Carduus pycnocephalus

Carex spp.

Carthamus lanatus

Carthamus leucocaulos

Cassia artemisioides
Table 2 (Continued)

Cassia barclayana

Cassia floribunda

Cassia obtusifolia

Cassia occidentalis

Cassinia arcuata

Cassinia quinquefaria

Casuaria cristata

Cenchus echinatus

Centaurea biebersteinii

Centaurea diffusa

Centaurea maculosa

Centaurea melitensis

Centaurea nigra

Centaurea solstitialis

Cestrum spp.

Chamaecytisus proliferus

Cheilanthes spp.

Chenopodium album

Chenopodium nitrariacem

Chloris spp.

Chondrilla juncea

Chrysanthemoides monilifera

Cichorium intybus

Cineraria lyrata

Cinnamomum camphora

Cirsium arvense

Cirsium palustre

Cirsium vulgare

Citrullus colocynthis

Citrullus lanatus

Codonocarpus spp.

Coleogyne ramosissima

Conium maculatum

Convolvulus arvensis

Conyza albida

Coreopsis lanceolata

Cortaderia spp.

Cotoneaster spp.

Cotula australis

Craspedia spp.

Crataegus spp.

Crotolaria spp.

Cryptostegia grandiflora

Cucumis myriocarpus

Cuscuta spp.

Cycas spp.

Cynara cardunculus

Cynodon dactylon

Cynoglossum officinale

Cyperus aromaticus

Cyperus rotundus

Cytisus scoparius

Danthonia spp.

Diplotaxis tenuifolia

Discaria toumatou

Ditrichia graveolens

Dodonaea attenuata

Dodonaea viscosa

Echium plantagineum

Echium vulgare

Eleusine indica

Emex australis

Equisetum arvense

Equisetum pratense

Eragrostis australasia

Eragrostis curvula

Eremophila longifolia

Eremophila mitchellii

Erodium spp.

Erythrina spp.

Erythroxylum coca

Eucalyptus albens 
Table 2 (Continued)

Eucalyptus cladocalyx

Eucalyptus melliodora

Eucalyptus polyanthemos

Eucalyptus populnea

Euphorbia esula

Foeniculum vulgare

Froelichia floridana

Fragaria virginiana

Galenia pubescens

Gastrolobium spp.

Gaura parviflora

Geijera parviflora

Genista linifolia

Genista monspessulana

Gleditisia triacanthos

Gnaphalium spp.

Gomphrena globosa

Gorteria personata

Haloragis aspera

Heliotropium europaeum

Hedera spp.

Heterodendrum oleifolium

Hibiscus trionum

Hieracium spp.

Hirschfeldia incana

Homeria spp.

Hordeum leporinum

Hydrangea spp.

Hyparrhenia hirta

Hypericum androsaemum

Hypericum tetrapterum

Hypericum triquetrifolium

Hypochaeris radicata

Ilex spp.

Imperata cylindrica

Ipomoea lonchophylla

Ipomoea plebeia

Ipomoea purpurea

Iva axillaris

Juncus acutus

Juncus effusus

Juncus gregiflorus

Juniperus coahuilensis

Juniperus virginiana

Juniperus spp.

Laburnum spp

Lactuca serriola

Lantana camara

Laurel spp.

Lavandula stoechas

Lepidium latifolium

Leucaena spp.

Leucanthemum vulgare

Ligustrum lucidum

Ligustrum sinense

Lolium spp.

Lomandra longifolia

Lonicera japonica

Lycium ferocissimum

Maclura pomifera

Maireana spp.

Malva parsiflora

Marvella leprosa

Marrubium vulgare

Medicago falcata

Medicago sativa

Melia azedarach

Melilotus albus

Mentha spp.

Muehlenbeckia adpressa

Muehlenbeckia cunninghamii

Muhlenbergia schreberi
Table 2 (Continued)

Myagrum perfoliatum

Myoporum spp.

Nassella neesiana

Nassella trichotoma

Nicandra physalodes

Nicotiana glauca

Olea europaea

Olearia elliptica

Onopordum acanthium

Onopordum acaulon

Onopordum illyricum

Opuntia inermis

Opuntia stricta

Owenia acidula

Oxalis latifolia

Oxalis pes-caprae

Paraver seminiferum

Parkinsonia aculeata

Parthenium hysterophorus

Pennisetum clandestinium

Pennisetum acrourum

Pennisetum villosum

Pentzia suffruticosa

Pinus halepensis

Persicaria spp.

Phalaris minor

Pharagmites australis

Phyla canescens

Physalis virginiana

Physalis viscosa

Phytolacca octandra

Pinus halepensis

Pinus radiata

Pinus spp.

Poa labillardieri

Polygonum aviculare

Polypogon monspeliensis

Portulaca oleracea

Proboscidea louisianica

Prosopis cineraria

Prosopis glandulosa

Prosopis juliflora

Prunus persica

Pteridium esculentum

Pueraria montana

Pyracantha spp.

Quercus havardii

Quercus marilandica

Ranunculus spp.

Raphanus raphanistrum

Rapistrum rugosum

Reseda spp.

Rhododendron spp.

Ricinus communis

Robinia pseudoacacia

Romulea rosea

Rosa canina

Rosa micrantha

Rosa multiflora

Rosa rubiginosa

Rubus discolor

Rubus fruticosus agg.

Rubus oklahomas

Rumex acetosella

Rumex brownii

Rumex obtusifolius

Rumex brownii

Rumex conglomeratus

Rumex crispus

Rumex obtusifolius

Rumex pulcher

Salsola kali 


\section{Table 2 (Continued)}

$$
\begin{aligned}
& \text { Salvia reflexa } \\
& \text { Schinus spp. } \\
& \text { Sclerolaena birchii } \\
& \text { Sclerolaena muricata } \\
& \text { Scolymus hispanicus } \\
& \text { Senecio jacobaea } \\
& \text { Senecio madagascariensis } \\
& \text { Senecio pterophorus } \\
& \text { Senecio quadridentatus } \\
& \text { Senecio vulgaris } \\
& \text { Senna artemisioides } \\
& \text { Senna barclayana } \\
& \text { Sericea lespedeza } \\
& \text { Sida acuta } \\
& \text { Sida cordifolia } \\
& \text { Sida rhombifolia } \\
& \text { Silybum marianum } \\
& \text { Sisymbrium officinale } \\
& \text { Solanum carolinense } \\
& \text { Solanum elaeagnifolium } \\
& \text { Solanum mauritianum } \\
& \text { Solanum nigrum } \\
& \text { Soliva pterosperma } \\
& \text { Sonchus spp. } \\
& \text { Sorghum halepensse } \\
& \text { Sporobolus caroli } \\
& \text { Sporobolus indicus } \\
& \text { Sporobolus pyramidalis } \\
& \text { Stachys arvensis } \\
& \text { Stypandra glauca } \\
& \text { Stevia eupatoria } \\
& \text { Stipa caudata } \\
& \text { Swainsona spp. } \\
& \text { Syncarpia glomulifera } \\
& \text { Taeniatherum caput-medusae } \\
& \text { Tagetes minuta } \\
& \text { Tamarix ramosissima } \\
& \text { Taraxacum officinale } \\
& \text { Thunbergia grandiflora } \\
& \text { Toxicodendron diversilobum } \\
& \text { Toxicodendron vernix } \\
& \text { Toxicodendron radicans } \\
& \text { Toxicodendron succedaneum } \\
& \text { Tribulus terrestris } \\
& \text { Trifolium spp. } \\
& \text { Typha spp. } \\
& \text { Ulex europaeus } \\
& \text { Ulex gallii } \\
& \text { Ulmus spp. } \\
& \text { Urochloa panicoides } \\
& \text { Urtica incisa } \\
& \text { Ventilago viminalis } \\
& \text { Verbascum thapsus } \\
& \text { Verbena tenuisecta }
\end{aligned}
$$

Source: Popay and Field (1996), Simmonds et al. (2000), and Launchbaugh (2006).

\section{Climate change, water use and global warming}

Climate change and future water shortages are some of the most serious challenges facing the human race. The relevance of goats rises during periods of cyclical and unpredictable feed shortages, such as droughts. For example, the replacement of cattle by dromedaries and of sheep by goats in the Sahel followed the droughts of the 1980s (Hoffmann, 2010). After severe droughts, goat's populations recover faster than other ruminants due to factors such as their shorter gestation period or their lower mortality rate, providing food (e.g. milk) even before other resources (e.g. cereals) are available (Wilson, 1991).

The livestock sector demands $8 \%$ of the global human water use, mostly for the irrigation of feedcrops (Steinfeld et al., 2006). For example, 500 L of water is needed in Kenya to produce $\$ 2$ income from growing grain whereas it takes $4 \mathrm{~L}$ of water to produce $\$ 2$ income from goat milk (Peacok and Sherman, 2010).

Livestock accounts for about 37\% of all anthropogenic methane emissions related to the global warming (Steinfeld et al., 2006), and it is greatly related to the expansion of beef production (Peacok and Sherman, 2010). Furthermore, most of the emissions from manure derive from pigs, beef cattle feedlots and dairy farms, where manure is stored in anaerobic conditions (Steinfeld et al., 2006; FAO, 2009), which is seldom the case in goat systems.

\section{Goats as a feed resource for other species}

Small ruminants are some of the major components of the diet of certain carnivores and scavengers. Domestic goats made up to $43 \%$ of the total depredation cases of the Eurasian lynx (Lynx lynx Linnaeus 1958), listed as "near threatened" by the International Union for Conservation of Nature (IUCN) in Pakistan (Din and Nawaz, 2010). They represented around $32 \%$ of the prey for wild predators in India, mainly by the Tibetan wolf (Canis lupus chanko Gray, 1863), "vulnerable" according to the IUCN, and the snow leopard (Uncia uncia (Schreber, 1775)), a "highly endangered" species (Namgail et al., 2007). Domestic animals can also be an important target for wolves, a carnivore which is increasing in numbers in both Europe and North America and is beginning to reoccupy semi-wilderness and agricultural lands (Boitani, 2003). Livestock predation has caused human-wildlife conflicts in many places, especially in the Alpine zones of the world where livestock rearing is the major source of income (Din and Nawaz, 2010).

In Picos de Europa National Park (northern Spain), domestic small ruminants have been a feed resource for wolves and several species of scavenger birds such as bearded vultures (Gypaetus barbatus Linnaeus, 1758), Eurasian griffon vultures (Gyps fulvus Hablizl, 1783) and Egyptian vultures (Neophron percnopterus Linnaeus, 1758). They are threatened birds in Europe (Annex I, EU Wild Birds Directive 79/409/EEC, Appendix II of the Bern Convention, Bonn Convention and CITES) which require conservation priorities based on favouring extensive livestock practices. In the case of Eurasian griffon and Egyptian vulture, there is a clear relationship between the available biomass of sheep and goats and the density of these species (Margalida et al., 2007). Furthermore, the reintroduction program of the bearded vulture in northern Spain greatly depends on whether mountainous pastures and extensive livestock grazing (of small ruminants) are preserved (Báguena et al., 2007). Finally, a contradictory situation occurs in the Canary Islands (Spain), where introduced goats are responsible for the near-extinction of some endemic plants, 
whereas their populations support native scavengers and predators which include three endangered endemic subspecies of birds (Gangoso et al., 2006).

\section{Future perspectives}

The goat systems will have to face different global trends from the socio-economic and environmental points of view. They will have to respond to the increasing demand of a growing population in developing countries, who have aspirations and dietary choices closer to the developed countries, but also to maintain sustainable systems under new scenarios influenced by the global warming and the environmental degradation, while coping with the rising costs of non-renewable energy or grain (Peacok and Sherman, 2010). In addition, the developing and the developed areas have to confront different difficulties. The poorer areas require an improvement of the social and political conditions to ensure a long term sustainable application of environmentally friendly management strategies. For example, the restoration of the cashmere trade in Afghanistan after years of war and prolonged droughts could contribute to the recovery of the economy while minimizing adverse environmental consequences, only if economic and socio-political decisions in the future attend to reasonable grazing strategies. Mongolia and China had responded to an increasing market demand for cashmere with increasing government subsidies and goat numbers to a point beyond the carrying capacity of rangelands, so desertification emerged and the viability of the enterprises dropped (Osnos, 2006), exemplifying how incorrect and irrational policy decisions can affect environmental sustainability.

Adequate strategies to provide both environmental and social and economical benefits are known in other areas. Improved grazing and feeding schemes are recommended in northern mountainous areas of Oman to reduce the pressure on the natural vegetation, taking also into account local property rights, herding skills and the potential recovery of the vegetation (Schlecht et al., 2009). Similarly, Baraza et al. (2010) propose goat management strategies in the Mexican Biosphere Reserve of the Tehuacán-Cuicatlán Valley to improve the quality of life for the people living in the reserve without increasing anthropogenic environmental impact.

Within the developed countries, sustainable development based on environmental criteria is on the agenda of the most influential European governments and it has clearly carried weight on EU agricultural policy. Nevertheless, the income provided by ecologically sustainable low-input goat systems may be insufficient to sustain the next generation, so there is a greater risk of becoming marginalized (e.g. de Rancourt et al., 2006; Dýrmundsson, 2006; Peacok and Sherman, 2010). In addition, further increases of the productivity in certain areas are limited by the carrying capacity of the land, nutritive quality of the vegetation and sustainability, environmental protection, animal health, animal welfare or product quality (Dýrmundsson, 2006). Nevertheless, goat systems might have a chance in new niche markets that demand high quality products such as cheese, yogurt, goat-milk soap, and high quality textile fibre, which may also help to maintain traditional farming in harmony with the needs of landscapes and habitat conservation (Boyazoglu and Morand-Fehr, 2001; Lu et al., 2010). In addition, small ruminant management should also be compatible with recreational, cultural, or scientific purposes (Ronchi and Nardone, 2003). The organic goat production might achieve a great part of these goals, as it can protect the environment, improve animal welfare and sustain rural live styles. This sector has increased substantially during the past decade and its demand is expected to continue growing at a rate of $10-30 \%$ per year. This activity is especially promising to increase the income of goat producers operating in marginal lands as results of incomes from externalities, but it still requires more research on alternative nutrition and alternative treatments for disease prevention (Lu et al., 2010).

\section{Concluding remarks}

This paper has reviewed some of the most important issues concerning the environmental impacts of goat grazing worldwide and some of the main challenges that are to be confronted in a politically, socioeconomically and climatologically changing world where sustainable management strategies should be encouraged. The urgency of confronting these challenges has been highlighted during the IGAs' Meeting, (Dubeuf, 2011) or in the Global Plan of Action for Animal Genetic Resources (FAO, 2007), but the current knowledge is not summarized for many issues although it could provide basic guidelines for future projects.

Most of the environmentally harmful effects of goat grazing are linked to improper management practices and various examples of how it can be a powerful and environmentally friendly tool if managed adequately to the environmental and socioeconomic context of each area are mentioned.

More efforts to preserve and study the genetic heritage associated to goat breeds are needed, starting from the agricultural policy makers at both national and international level. Such efforts should run in parallel with rural development, especially in remote areas where rural communities endure adverse conditions managing for their survival an outstanding reservoir of livestock diversity mostly unknown to us.

One of the most effective tools to guarantee the persistence of any management or conservation program relies on the participation of scientists, policy makers, rangeland managers and local communities or farmers. In full agreement with Dubeuf (2011), local know-how has to be considered a valuable tool to be incorporated in new methodologies which will be enriched with the academic knowledge. The results of this fusion must be disseminated on two ways, to the scientist community and to the local communities to help them to manage their livestock in a sustainable way. In summary, the information from different sources must be put together and participation and education should be prioritized. 
The multidisciplinary approach should be extended to the scientific community when analysing the implications of management strategies as they tend to be focused either on environmental, socioeconomical or production perspectives, while they are rarely considered simultaneously and that would be highly desirable to define sustainable strategies. This would allow meeting those goals of the Interlaken Convention which considered necessary a co-management of the various components of biological diversity, including soils, crops, rangelands and pastures, fodder crops and wildlife (FAO, 2007).

One of the strategies which have already proved to be efficient is the management of mixed flocks of goats with other livestock under moderate grazing pressure. It will contribute to the diversification of the production and to enhance animal performance of other domestic herbivores, landscape biodiversity by reducing fire risk and the economic conditions in marginal areas as suggested by Osoro et al. (1999).

Low input goat systems which provide high quality products and organic goat production are among the best options to develop sustainable management alternatives which are also environmentally friendly.

As a summary, this manuscript highlights that the consideration of goats in general as harmful for the environment is erroneous. Numerous studies prove that moderate grazing pressures can be compatible with high levels of biodiversity and can provide externalities which support population, whereas high grazing pressures can be valuable tools for weed control. The conservation of the genetic heritage has multiple implications as many autochthonous breeds better adapted to resist pathogens than exotic ones are threatened together with the local communities which manage them despite their relevance as a precious reservoir of biodiversity to confront the impending climatological and socioeconomical challenges.

\section{Acknowledgements}

The authors thank the anonymous reviewers and the Editor for their helpful suggestions and constructive comments.

\section{References}

Abbott, I., Marchant, N., Cranfield, R., 2000. Long-term change in the floristic composition and vegetation structure of Carnac Island, Western Australia. J. Biogeogr. 27, 333-346.

Acevedo, P., Cassinello, J., 2009. Human-induced range expansion of wild ungulates causes niche overlap between previously allopatric species: red deer and Iberian ibex in mountainous regions of southern Spain. Ann. Zool. Fennici 46, 39-50.

Acevedo, P., Cassinello, J., Gortazar, C., 2007. The Iberian ibex is under an expansion trend but displaced to suboptimal habitats by the presence of extensive goat livestock in central Spain. Biodivers. Conserv. 16 , 3361-3376.

Adams, T.E., Hughes, C.L., 1977. Want biological brush control? Try goats! Rangeman's J. 4, 4.

Aldezabal, A., 2001. El sistema de pastoreo del Parque Nacional de Ordesa y Monte Perdido (Pirineo Aragonés, Aragón). Interacción entre la vegetación supraforestal y los grandes herbívoros. In: Consejo de Protección de la Naturaleza de Aragón, Zaragoza, Spain.

Aldezabal, A., Garin, I., 2000. Browsing preference of feral goats (Capra hircus L.) in a Mediterranean mountain scrubland. J. Arid Environ. 44, 133-142.
Arévalo, J.R., de Nascimento, L., Fernández-Lugo, S., Camacho, A., Mata, J., Bermejo, L., 2011. Effects of abandoning long-term goat grazing on species composition and species richness of pastures at La Gomera, Canary Islands. Span. J. Agric. Res. 9, 113-123.

Augustine, D.J., McNaughton, S.J., 2004. Regulation of shrub dynamics by native browsing ungulates on East African rangeland. J. Appl. Ecol. 41, 45-58.

Bagchi, S., Mishra, C., Bhatnagar, Y.V., 2004. Conflicts between traditional pastoralism and conservation of Himalayan ibex (Capra sibirica) in the Trans-Himalayan Mountains. Anim. Conserv. 7, 121-128.

Báguena, G., Sánchez-Castilla, E., Antor, R.J., 2007. Criterios para la reintroducción de una especie amenazada: el quebratahuesos en el Parque Nacional de los Picos de Europa. In: Organismo Autónomo Parques Nacionales y Medio Ambiente, Ministerio de Medio Ambiente, Madrid.

Baraza, E., Valiente-Banuet, A., Delgado, O.D., 2010. Dietary supplementation in domestic goats may reduce grazing pressure on vegetation in semi-arid thornscrub. J. Arid Environ. 74, 1061-1065.

Baraza, E., Valiente-Banuet, A., 2008. Seed dispersal by domestic goats in a semiarid thornscrub of Mexico. J. Arid Environ. 72, 1973-1976.

Bartolomé, J., 1994. Ecologia dels ramats d'oví I cabrum al Pla de la Calma. Ph.D. Thesis. Universitat Autònoma de Barcelona, Bellaterra, Spain.

Benavides, R., Celaya, R., Ferreira, L.M.M., Jáuregui, B.M., García, U., Osoro, K., 2009. Grazing behaviour of domestic ruminants according to flock type and subsequent vegetation changes on partially improved heathlands. Span. J. Agric. Res. 7, 417-430.

Bhatnagar, Y.V., 1997. Ranging and habitat utilization by the Himalayan ibex (Capra ibex sibirica) in Pin Valley National Park. Ph.D. Thesis. Saurashtra University, Rajkot, India.

Bhatnagar, Y.V., Wangchuk, R., Prins, H.H.T., Van Wieren, S.E., Mishra, C., 2006. Perceived conflicts between pastoralism and conservation of the Kiang Equus kiang in the Ladakh Trans-Himalaya, India. Environ. Manage. 38, 934-941.

Bläß, C., Ronnenberg, K., Tackenberg, O., Hensen, I., Wesche, K., 2010. The relative importance of different seed dispersal modes in dry Mongolian rangelands. J. Arid Environ. 74, 991-997.

Blázquez, M.S., García-Adamez, M.M.A., Flamant, J.C., Portugal, A.V., Costa, J.P., Nunes, A.F., Boyazoglu, J., 1995. Le tourisme rural dans les regions defavorisees: une approche globale impliquant les animaux comme alternative pour le developpement. In: Flamant, J.C., Portugal, A.V., Costa, J.P., Nunes, A.F., Boyazoglu, J. (Eds.), Animal Production and Rural Tourism in Mediterranean Regions, Proceedings of the International Symposium on Animal Production and Rural Tourism in Mediterranean Regions. Wageningen Press, Wageningen, The Netherlands, pp. 271-274.

Boitani, L., 2003. Wolf conservation and recovery. In: Mech, L.D., Boitani, L. (Eds.), Wolves: Behaviour, Ecology and Conservation. University of Chicago Press, Chicago, USA, pp. 317-340.

Booth, A.L., Skelton, N.W., 2009. The use of domestic goats and vinegar as municipal weed control alternatives. Environ. Pract. 11, 3-16.

Boyazoglu, J., Morand-Fehr, P., 2001. Mediterranean dairy sheep and goat products and their quality. A critical review. Small Rumin. Res. 40, $1-11$.

Breebaart, L., Bhikraj, R., O’Connor, T.G., 2002. Dietary overlap between Boer goats and indigenous browsers in a South African savanna. Afr. J. Range Forage Sci. 19, 13-20.

Brock, J.H., 1988. Livestock: biological control in brush/weed management programs. Rangelands 10, 32-34.

Bryant, F.C., Kothmann, M.M., Merrill, L.B., 1979. Diets of sheep, Angora goats, Spanish goats and white-tailed deer under excellent range conditions. J. Range Manage. 32, 412-417.

Bueno, C.G., Alados, C.L., Gómez, D., Barrio, I.C., García, R., 2009. Understanding the main factors in the extent and distribution of wild boar rooting on alpine grasslands. J. Zool. 279, 195-202.

Bullock, D.J., North, S., Dulloo, M.E., Thorsen, M., 2002. The impact of rabbit and goat eradications on the ecology of Round Island, Mauritius. In: Veitch, C.R., Clout, M.N. (Eds.), Turning the Tide: The Eradication of Invasive Species. IUCN Species Survival Commission, Gland, Switzerland/Cambridge, UK, pp. 53-63.

Camacho Vallejo, M.E., Martínez Martínez, A., León Jurado, J.M., Cabello Robles, A., de la Haba Giraldo, M.R., Vallecillo, A., Delgado Bermejo, J.V., 2005. La raza caprina Blanca Andaluza: estrategias para su caracterización y conservación. Arch. Zootec. 54, 151-156.

Camacho, M.E., Vallecillo, A., Martínez, A., Miró-Arias, M., Méndez, Y., Pons, A., Delgado, J.V., 2011. Pitiüsa-Ibicenca goat conservation program: current status. Small Rumin. Res. 98, 189-191.

Campbell, K., Donlan, J., 2005. Feral goat eradications on islands. Conserv. Biol. 19, 1362-1374. 
Campos-Arceiz, A., Takatsuki, S., Lhagvasuren, B., 2004. Food overlap between Mongolian gazelles and livestock in Omnogobi, southern Mongolia. Ecol. Res. 19, 455-460.

Canali, G., 2006. Common agricultural policy reform and its effects on sheep and goat market and rare breeds conservation. Small Rumin. Res. 62, 207-213.

Castel, J.M., Ruiz, F.A.B., Mena, Y., Sánchez-Rodríguez, M., 2010. Present situation and future perspectives for goat production systems in Spain. Small Rumin. Res. 62, 207-210.

Celaya, R., Jáuregui, B.M., Rosa García, R., Benavides, R., García, U., Osoro, K., 2010. Changes in heathland vegetation under goat grazing: effects of breed and stocking rate. Appl. Veg. Sci. 13, 125-134.

Celaya, R., Martínez, A., Osoro, K., 2007. Vegetation dynamics in Cantabrian heathlands associated with improved pasture areas under single or mixed grazing by sheep and goats. Small Rumin. Res. 72, 165-177.

Choquenot, D., Caughley, J., McLeod, S., 1998. Scientific, Economic and Social Issues of Commercial Use of Wild Animals in Australia. Bureau of Resource Sciences, Canberra, Australia.

Clark, D.A., Rolston, M.P., Lambert, M.G., Budding, P.J., 1984. Pasture composition under mixed sheep and goat grazing on hill country. Proc. N. Z. Grassl. Assoc. 45, 160-166.

Coblentz, B.E., 1978. The effects of feral goats (Capra hircus) on island ecosystems. Biol. Conserv. 13, 279-286.

Coblenz, B.E., van Vuren, D., Main, M.B., 1990. Control of feral goats on Aldabra atoll. Atoll Res. Bull. 337, 2-10.

Cuartas, P., 1992. Herbivorismo de grandes mamíferos en un ecosistema de montaña mediterránea. Ph.D. Thesis. Universidad de Oviedo, Oviedo, Spain.

Davis, G.G., Bartel, L.E., Cook, C.W., 1975. Control of Gambel oak sprouts by goats. J. Range Manage. 28, 216-218.

Dawson, T.J., Ellis, B.A., 1994. Did dietary competition play a role in the extinction of small macropodids in western New South Wales with the coming of European settlement? In: Lunney, D., Hand, S., Reed, Ph., Butcher, D. (Eds.), Future of the Fauna of Western New South Wales. Royal Zoological Society of NSW, Mosman, pp. 75-80.

Dawson, T.J., Ellis, B.A., 1996. Diets of mammalian herbivores in Australian arid, hilly shrublands: seasonal effects on overlap between euros (hill kangaroos), sheep and feral goats, and on dietary niche breadths and electivities. J. Arid Environ. 34, 491-506.

de Rancourt, M., Fois, N., Lavín, M.P., Tchakérian, E., Vallerand, F., 2006. Mediterranean sheep and goats production: an uncertain future. Small Rumin. Res. 62, 167-179.

Decaix, G., 1994. Sylvopastoralisme dans le Haut-Verdon. Rev. For. Fr. 46, 49-58.

del Pozo, M., Wright, I., Whyte, T.K., Colgrove, P.M., 1996. Effects of grazing by sheep or goats on sward composition in ryegrass/white clover pasture and on subsequent performance of weaned lambs. Grass Forage Sci. 51, 142-154.

del Pozo, M., Osoro, K., Celaya, R., 1998. Effects of complementary grazing by goats on sward composition and on sheep performance managed during lactation in perennial ryegrass and white clover pastures. Small Rumin. Res. 29, 173-184.

Dennis, R.L.H., 2004. Just how important are structural elements as habitat components? Indications from a declining lycaenid butterfly with priority conservation status. J. Insect Conserv. 8, 37-45.

Desender, K., Baert, L., Maelfait, J.-P., Verdyck, P., 1999. Conservation on Volcán Alcedo (Galápagos): terrestrial invertebrates and the impact of introduced feral goats. Biol. Conserv. 87, 303-310.

Devendra, C., 2010. Concluding synthesis and the future for sustainable goat production. Small Rumin. Res. 89, 125-130.

Din, J.U., Nawaz, M.A., 2010. Status of the Himalayan lynx in district Chitral, NWFP, Pakistan. J. Anim. Plant Sci. 20, 17-22

Dolek, M., Geyer, A., 2002. Conserving biodiversity on calcareous grasslands in the Franconian Jura by grazing: a comprehensive approach. Biol. Conserv. 104, 351-360.

Donlan, C.J., Campbell, K., Cabrera, W., Lavoie, C., Carrion, V., Cruz, F., 2007. Recovery of the Galápagos rail (Laterallus spilonotus) following the removal of invasive mammals. Biol. Conserv. 138, $520-524$.

Dubeuf, J.-P., 2011. The social and environmental challenges faced by goat and small livestock local activities: present contribution of research-development and stakes for the future. Small Rumin. Res. $98,3-8$.

Duchev, Z., Distl, O., Groeneveld, E., 2006. Early warning system for loss of diversity in European livestock breeds. Arch. Tierz. Dummerstorf 49 , 521-531.

Dýrmundsson, O.R., 2006. Sustainability of sheep and goat production in North European countries - from the Arctic to the Alps. Small Rumin. Res. 62, 151-157.
El Aich, A., Waterhouse, A., 1999. Small ruminants in environmental conservation. Small Rumin. Res. 34, 271-287.

Etienne, M., Derzko, M., Rigolot, E., 1996. Browse impact in silvopastoral systems participating in fire prevention in French Mediterranean region. In: Étienne, M. (Ed.), Western European Silvopastoral Systems. INRA Editions, Versailles, France, pp. 93-102.

Etzenhouser, M.J., Owens, M.K., Spalinger, D.E., Murden, S.B., 1998. Foraging behavior of browsing ruminants in a heterogeneous landscape. Landscape Ecol. 13, 55-64.

Fajemisin, B., Ganskopp, D., Cruz, R., Vavra, M., 1996. Potential for woody plant control by Spanish goats in the sagebrush steppe. Small Rumin. Res. 20, 229-238.

FAO, 2007. Global Plan of Action for Animal Genetic Resources and the Interlaken Declaration. Food and Agriculture Organization of the United Nations, Rome.

FAO, 2009. The State of Food and Agriculture. Livestock in the Balance. Food and Agriculture Organization of the United Nations, Rome.

FAO, 2010a. La situación de los recursos zoogenéticos mundiales para la alimentación y la agricultura. Comisión de Recursos Genéticos para la alimentación y la Agricultura, Organización de las Naciones Unidas para la Agricultura y la Alimentación, Rome.

FAO, 2010b. Status and Trends of Animal Genetic Resources - 2010. Intergovernmental Technical Working Group on Animal Genetic Resources for Food and Agriculture. Sixth Session. Commission on Genetic Resources for Food and Agriculture, FAO, Rome (accessed 18.03.11) http://www.fao.org/ag/againfo/programmes/en/genetics/documents ITWG_AnGR_6/CGRFA_WG_AnGR_6_10_inf_3.pdf.

FAOSTAT, 2001. CD-ROM. FAO, Rome, Italy.

Fatmann, T., 2006. Oviposition preferences, adjacency of old woodland and isolation explain the distribution of the Duke of Burgundy butterfly (Hamearis lucina) in calcareous grasslands in central Germany. Ann. Zool. Fennici 43, 335-347.

Fernández-Lugo, S., de Nascimiento, L., Mellado, M., Bermejo, L.A., Arévalo, J.R., 2009. Vegetation change and chemical composition after four years of goat grazing exclusion in a Canary Island pasture. Agric. Ecosyst. Environ. 132, 276-282.

Ferrer, C., Barrantes, O., Broca, A., 2001. La noción de biodiversidad en los ecosistemas pascícolas españoles. Pastos 31, 129-184

Figueroa, P., Fernández, I., Gómez, E., Royo, L.J., Álvarez, I., Goyache, F., 2003. Iniciativas de conservación de la cabra de raza Bermeya de Asturias. Anim. Genet. Resour. Inf. 33, 57-71.

Flamant, J.C., Béranger, C., Gibon, A., 1999. Animal production and land use sustainability. An approach from the farm diversity at territory level. Livestock Prod. Sci. 61, 275-286.

Fraser, M.D., Gordon, J., 1997. The diet of goat, red deer and South American camelids feeding on three contrasting Scottish upland vegetation communities. J. Appl. Ecol. 34, 668-686.

Gallego, F.L., Urban, F.P., Gonzales, L.G., Flamant, J.C., Portugal, A.V., Costa, J.P., Nunes, A.F., Boyazoglu, J., 1995. Model of animal production integrated in the programme of rural tourism, in "La Serena" Region (Extremadura, Spain). In: Flamant, J.C., Portugal, A.V., Costa, J.P. (Eds.), Animal Production and Rural Tourism in Mediterranean Regions. Wageningen Press, Wageningen, The Netherlands, pp. 233-242.

Galluzzi, G., Eyzaguirre, P., Negri, V., 2010. Home gardens: neglected hotspots of agro-biodiversity and cultural diversity. Biodivers. Conserv. 19, 3635-3654.

Gangoso, L., Donázar, J.A., Scholz, S., Placios, C., Hiraldo, F., 2006. Contradiction in conservation of island ecosystems: plants, introduced herbivores and avian scavengers in the Canary Islands. Biodivers. Conserv. 15, 2231-2248.

García-González, R., Cuartas, P., 1989. A comparison of the diets of the wild goat (Capra pyrenaica), domestic goat (Capra hircus), mouflon (Ovis musimon) and domestic sheep (Ovis aries) in the Cazorla mountain range. Acta Biol. Montana 9, 123-132.

Garcia-Gonzalez, R., Hidalgo, R., Montserrat, C., 1990. Patterns of time and space use by livestock in the Pyrenean summer ranges: a case study in the Aragon valley. Mt. Res. Dev. 10, 241-255.

Goehring, B.J., Launchbaugh, K.L., Wilson, L.M., 2010. Late-season targeted grazing of yellow starthistle (Centaurea solstitialis) with goats in Idaho. Invasive Plant Sci. Manage. 3, 148-154.

Gómez, J.M., García, D., Zamora, R., 2003. Impact of vertebrate acorn- and seedling-predators on a Mediterranean Quercus pyrenaica forest. Forest Ecol. Manage. 180, 125-134.

Gómez, M., Gorostiza, P., Urarte, E., 1998. Programa de conservación de las razas de ovino y caprino vascas en peligro de extinción. Prod. Ov. Capr. 23, 215-218.

González, L.M., San Miguel, A., 2004. Manual de buenas prácticas de gestión en fincas de monte mediterráneo de la red Natura 2000. Ministerio de Medio Ambiente, Madrid, 327 pp. 
Gordon, I.J., 1989. Vegetation community selection by ungulates on the Isle of Rhum. II. Vegetation community selection. J. Appl. Ecol. 26, 53-64.

Grant, S.A., Bolton, G.R., Russel, A.J.F., 1984. The utilization of sown and indigenous plant species by sheep and goats grazing hill pastures. Grass Forage Sci. 39, 361-370.

Gray, T., 1984. Goats curb weed problem. N. Z. Farmer 105, 13-14.

Green, L.R., Newell, L.A., 1982. Using goats to control brush regrowth on fuel breaks. General Technical Report PSW-59. United States Department of Agriculture, Pacific Southwest Forest and Range Experiment Station, Berkeley, CA.

Hall, S.J.G., 2004. Livestock Biodiversity: Genetic Resources for the Farming of the Future. Blackwell Publishing Ltd, Oxford, UK, 264 pp.

Hall, S.J.G., Ruane, J., 1993. Livestock breeds and their conservation: a global overview. Conserv. Biol. 7, 815-825.

Halvorson, W.L., Fenn, D.B., Allardice, W.R., 1988. Soils and vegetations of Santa Barbara Island, Channel Islands National Park, California, USA Environ. Manage. 12, 109-118.

Hamann, O., 1979. Regeneration of vegetation on Santa Fé and Pinta islands, Galápagos, after the eradication of goats. Biol. Conserv. 5, 215-235.

Hanselka, C.W., Paschal, J.C., 1992. Brush utilization on the Rio Grande Plains. Rangelands 14, 169-171.

Harradine, A.R., Jones, A.L., 1985. Control of gorse regrowth by Angora goats in the Tasmanian Midlands. Aust. J. Exp. Agric. 25, 550-556.

Harris, R.B., Loggers, C.O., 2004. Status of Tibetan plateau mammals in Yeniugou, China. Wildl. Biol. 10, 91-99.

Harris, R.B., Miller, D.J., 1995. Overlap in summer habitats and diets of Tibetan plateau ungulates. Mammalia 59, 197-212.

Harris, R.B., Pletscher, D.H., 2002. Incentives toward conservation of argali Ovis ammon: a case study of trophy hunting in western China. Oryx 36, 373-381.

Hart, S.P., 2001. Recent perspectives in using goats for vegetation management in the USA. J. Dairy Sci. 84, 170-176.

Hein, D.G., Miller, S.D., 1992. Influence of leafy spurge on forage utilization by cattle. J. Range Manage. 45, 405-407.

Hoffmann, I., 2010. Livestock biodiversity. Rev. Sci. Tech. Off. Int. Epiz. 29 73-86.

Holmst, P.J., 1980. The use of goats in grazing systems and their place in weed control. Proc. Aust. Soc. Anim. Prod. 13, 188-191.

Holst, P.J., Allan, C.J., Campbell, M.H., Gilmour, A.R., 2004. Grazing of pasture weeds by goats and sheep. 1. Nodding thistle (Carduus nutans). Aust. J. Exp. Agric. 44, 547-551.

Hoppe, P.P., Quortrup, S.A., Woodford, M.H., 1977. Rumen fermentation and food selection in East African sheep, goats, Thomson's Gazelle, Grant's Gazelle and Impala. J. Agric. Sci. Camb. 89, 129-135.

Huss, D.L., 1972. Goat response to use of shrubs as forage. In: McKell, C.M., Blaisdell, J.P., Goodin, J.R. (Eds.), Wildland Shrubs - Their Biology and Utilization. General Technical Report 1. United States of America Forest Service, Ogden, UT, USA, pp. 331-338.

Jáuregui, B.M., García, U., Osoro, K., Celaya, R., 2009. Sheep and goat grazing effects on three Atlantic heathland types. Rangeland Ecol. Manage. 62 119-126.

Jauregui, B.M., Rosa Garcia, R., Garcia, U., WallisDeVries, M.F., Osoro, K., Celaya, R., 2008. Effects of stocking density and breed of goats on vegetation and grasshopper occurrence in heathlands. Agric. Ecosyst. Environ. 123, 219-224.

Kittur, S., Sathyakumar, S., Rawat, G.S., 2010. Assessment of spatial and habitat use overlap between Himalayan tahr and livestock in Kedarnath Wildlife Sanctuary, India. Eur. J. Wildl. Res. 56, 195-204.

Lacey, J.R., Marlow, C.B., Lane, J.R., 1989. Influences of spotted knapweed (Centaurea maculosa) on surface runoff and sediment yield. Weed Technol. 3, 627-631.

Launchbaugh, K. (Ed.), 2006. Targeted Grazing: A Natural Approach to Vegetation Management and Landscape Enhancement. Cottrell Printing, Centennial, CO, USA

Lu, C.D., Gangyi, X., Kawas, J.R., 2010. Organic goat production, processing and marketing: opportunities, challenges and outlook. Small Rumin. Res. 89, 102-109.

Luginbuhl, J.M., Harvey, T.E., Green, J.T., Poore, M.H., Mueller, J.P., 1999 Use of goats as biological agents for the renovation of pastures in the Appalachian region of the United States. Agroforest. Syst. 44, 241-252.

Lym, R.G., 1998. The biology and integrated management of leafy spurge (Euphorbia esula) on North Dakota rangeland. Weed Technol. 12, 367-373.

Lym, R.G., Sedivec, K.K., Kirby, D.R., 1997. Leafy spurge control with angora goats and herbicides. J. Range Manage. 50, 123-128.

Madhusudan, M.D., 2004. Recovery of wild large herbivores following livestock decline in a tropical Indian wildlife reserve. J. Appl. Ecol. 41, 858-869.
Magadlela, A.M., Dabaan, M.E., Bryan, W.B., Prigge, E.C., Skousen, J.G., D'Souza, G.E., Arbogast, B.L., Flores, G., 1995. Brush clearing on hill land pasture with sheep and goats. J. Agron. Crop Sci. 174, 1-8.

Mahanjana, A.M., Cronje, P.B., 2000. Factors affecting goat production in a communal farming system in the Eastern Cape region of South Africa. S. Afr. J. Anim. Sci. 30, 149-154.

Mancilla-Leytón, J.M., Fernández-Alés, R., Martín Vicente, A., 2011. Plant-ungulate interaction: goat passage affect on survival and germination of Mediterranean shrub seeds. J. Veg. Sci. 22, 1031-1037.

Margalida, A., García, D., Cortés-Avizanda, A., 2007. Factors influencing the breeding density of Bearded Vultures, Egyptian Vultures and Eurasian Griffon Vultures in Catalonia (NE Spain): management implications. Anim. Biodivers. Conserv. 30, 189-200.

Martín, A., Mancilla-Leytón, J.M., Parejo, C., Fernández Alés, R., Leiva, M.J., 2011. The function of goat grazing in Doñana National Park. Opt. Méd. A 100, 173-178.

Martin, J.A., Huss, D.L., 1981. Goats much maligned but necessary. Rangelands 3, 199-201.

Martyniuk, E., Olech, W., 1997. Consideration of breeding objectives in small ruminants used for vegetation control and landscape maintenance. Opt. Méd. A 33, 221-229.

Mason, I.L., 1984. Evolution of Domesticated Animal. Longman, London, $452 \mathrm{pp}$.

Merchant, M., 1993. The potential for control of the soft rush (Juncus effusus) in grass pasture by grazing goats. Grass Forage Sci. 48 , 395-409.

Merrill, L.B., Taylor, C.A., 1981. Diet selection, grazing habits and place of goats in range management. In: Gall, C. (Ed.), Goat Production. Academic Press, London, pp. 233-252.

Milner, J., Bonenfant, C., Mysterud, A., Gaillard, J.M., Csányi, S., Stenseth, N.C., 2006. Temporal and spatial development of red deer harvesting in Europe - biological and cultural factors. J. Appl. Ecol. 43, 721-734.

Mishra, C., Prins, H.H.T., van Wieren, S.E., 2001. Overstocking in the transHimalayan rangelands of India. Environ. Conserv. 28, 279-283.

Mishra, C., Rawat, G.S., 1998. Livestock grazing and biodiversity conservation: comments on Saberwal. Conserv. Biol. 12, 712-717.

Mishra, C., van Wieren, S.E., Heitkönig, I., Herbert, M.A., Prins, H.H.T., 2002. A theoretical analysis of competitive exclusion in a Trans-Himalayan large-herbivore assemblage. Anim. Conserv. 5, 251-258.

Mishra, C., van Wieren, S.E., Ketner, P., Heitkonig, I.M.A., Prins, H.H.T., 2004. Competition between domestic livestock and wild bharal Pseudois nayaur in the Indian Trans-Himalaya. J. Appl. Ecol. 41, 344-354.

Muller, S., 2002. Appropriate agricultural management practices required to ensure conservation and biodiversity of environmentally sensitive grassland sites designated under Natura 2000. Agric. Ecosyst. Environ. 89, 261-266.

Namgail, T., Bhatnagar, Y.V., Mishra, C., Bagchi, S., 2007. Pastoral nomads of the Indian Changthang: production system, land use and socioeconomic changes. Hum. Ecol. 35, 497-504.

Namgail, T., Joseph, L., Fox, J.L., Bhatnagar, Y.V., 2009. Status and distribution of the Near Threatened Tibetan argali Ovis ammon hodgsoni in Ladakh, India: effect of a hunting ban. Oryx 43, 288-291.

Nyakatawa, E.Z., Mays, D.A., Naka, K., Bukenya, J., 2011. Carbon, nitrogen, and phosphorus dynamics in a loblolly pine-goat silvopasture system in the Southeast USA. Agroforest. Syst. http://dx.doi.org/10.1007/s10457-011-9431-2, in press.

Nyong, A., Adesina, F., Osman Elasha, B., 2007. The value of indigenous knowledge in climate change mitigation and adaptation strategies in the African Sahel. Mitig. Adapt. Strateg. Global Change 12 787-797.

Olsen, F.W., Hansen, R.M., 1977. Food relations of wild free-roaming horses to livestock and big game, Red Desert, Wyoming. J. Range Manage. 30, 17-20.

Ørskov, E.R., 2011. Goat production on a global basis. Small Rumin. Res. 98, 9-11.

Osnos, E., 2006. The Price We Pay for China's Boom (accessed 18.03.11) http://www.chicagotribune.com/news/nationworld/chi0612170360 dec17,0,7928608.story.

Osoro, K., Celaya, R., Martínez, A., 2000. The effects of mixed grazing with goats on performance of yearling calves in perennial ryegrass-white clover pastures. In: Rook, A.J., Penning, P.D. (Eds.), Grazing Management. The Principles and Practice of Grazing, for Profit and Environmental Gain, within Temperate Grassland Systems. British Grassland Society, Reading, UK, pp. 115-116, Occasional Symposium No. 34 .

Osoro, K., García, U., Jáuregui, B.M., Ferreira, L.M.M., Rook, A.J., Celaya, R., 2007. Diet selection and live-weight changes of two breeds of goats grazing on heathlands. Animal 1, 449-457. 
Osoro, K., Vassallo, J.M., Celaya, R., Martínez, A., 1999. Livestock production systems and the vegetation dynamics of Less Favoured Areas, (LFAs): developing viable systems to manage semi-natural vegetation in temperate LFAs in Spain. In: Laker, J.P., Milne, J.A. (Eds.), Livestock Production in the European Less Favoured Areas: Meeting Future Economic, Environmental and Policy Objectives Through Integrated Research. Macaulay Land Use Research Institute, Aberdeen, UK, pp. 133-143.

Owen-Smith, N., Cooper, S.M., 1985. Comparative consumption of vegetation components by kudus, impalas and goats in relation to their commercial potential as browsers in savanna regions. S. Afric. J. Sci. $81,72-76$

Papachristou, T.G., Papanastasis, V.P., 1994. Forage value of Mediterranean deciduous woody fodder species and its implication to management of silvo-pastoral systems for goats. Agroforest. Syst. 27, 269-282.

Parkes, J., Henzell, R., Pickles, G., 1996. Managing Vertebrate Pests: Feral Goats. Australian Government Publishing Service, Canberra.

Peacok, C., 1996. Improving Goat Production in the Tropics. A Manual for Development Workers. Oxfam-FARM-Africa, Oxford, UK.

Peacok, C., Sherman, D.M., 2010. Sustainable goat production. Some global perspectives. Small Rumin. Res. 89, 78-80.

Penning, P.D., Johnson, R.H., Orr, R.J., 1996. Effects of continuous stocking with sheep or goats on sward composition and animal production from a grass and white clover pasture. Small Rumin. Res. 21, 19-29.

Pérez Barbería, F.J., 1994. Biología, ecología y caracterización genética del rebeco cantábrico (Rupicapra pyrenaica parva). Ph.D. Thesis. Universidad de Oviedo, Spain.

Popay, I., Field, E., 1996. Grazing animals as weed control agents. Weed Technol. 10, 217-231.

Prins, H.H.T., 2000. Competition between wildlife and livestock in Africa. In: Prins, H.H.T., Grootenhuis, J.G., Dolan, T.T. (Eds.), Wildlife Conservation by Sustainable Use. Kluwer Academic Publishers, Boston, MA, USA, pp. 5-80.

Pritz, R.K., Launchbaugh, K.L., Taylor Jr., C.A., 1997. Effects of breed and dietary experience on juniper consumption by goats. J. Range Manage. $50,600-606$

Radcliffe, J.E., 1985. Grazing management of goats and sheep for gorse control. N. Z. J. Exp. Agric. 13, 181-190.

Radcliffe, J.E., Townsend, R.J., Baird, D.B., 1991. Mixed and separate grazing of sheep and goats at two stocking rates. N. Z. J. Agric. Res. 34, 167-176.

Reading, R.P., Amgalanbaatar, S., Mix, H., Badamjaviin, L., 1997. Argali Ovis ammon surveys in Mongolian's South Gobi. Oryx 31, 285-294.

Reading, R.P., Bedunah, D.J., Amgalanbaatar, S., 2006. Conserving biodiversity on Mongolian rangelands: implications for protected area development and pastoral uses. In: Bedunah, D.J., McArthur, E.D., Fernandez-Gimenez, M. (Eds.), Rangelands of Central Asia: Proceedings of the Conference on Transformations, Issues and Future Challenges. United States Department of Agriculture, Forest Service, Salt Lake City, UT, USA, pp. 1-17.

Rigueiro-Rodríguez, A., Mosquera, M.R., Romero, R., González, M.P., Villarino, J.J., 2005. Silvopastoral systems as a forest fire prevention technique. In: Mosquera-Losada, M.R., Rigueiro-Rodríguez, A., McAdam, J. (Eds.), Silvopastoralism and Sustainable Land Management. CAB International Congress, Wallingford, Oxfordshire, UK, pp. 380-387.

Robles, A.B., Boza, J., González Rebollar, J.L., 1997. Análisis de la recuperación de la cubierta pastoral en un agrosistema pastoral del sudeste semiárido ibérico. In: Hernández Bermejo, J.E., Clemente, M., Pujadas, A., Garrido, A., Pliego, F., Ubera, J.L. (Eds.), Actas Etnobotánica 92. Córdoba, Spain. Jardín Botánico de Córdoba, pp. 333-339.

Robles, A.B., Castro, J., González-Miras, E., Ramos, M.E., 2005. Effects of ruminal incubation and goats' ingestion on seed germination of two legume shrubs: Adenocarpus decorticans Boiss. and Retama sphaerocarpa (L.) Boiss. Opt. Méd. A 67, 111-115.

Ronchi, B., Nardone, A., 2003. Contribution of organic farming to increase sustainability of Mediterranean small ruminants livestock systems. Livestock Prod. Sci. 80, 17-31.

Rook, A.J., Dumont, B., Isselstein, J., Osoro, K., WallisDeVries, M.F., Parente, G., Mills, J., 2004. Matching type of grazing animal to desired biodiversity outcomes - a review. Biol. Conserv. 119, 137-150.

Rosa García, R., García, U., Osoro, K., Celaya, R., 2011. Ground-dwelling arthropod assemblages of partially improved heathlands according to the species of grazer and grazing regime. Eur. J. Entomol. 108, $107-115$.

Rosa García, R., Jáuregui, B.M., García, U., Osoro, K., Celaya, R., 2009a. Effects of livestock breed and grazing pressure on ground-dwelling arthropods in Cantabrian heathlands. Ecol. Entomol. 34, 466-475.

Rosa García, R., Jáuregui, B.M., García, U., Osoro, K., Celaya, R., 2009b. Responses of arthropod fauna assemblages to goat grazing management in northern Spanish heathlands. Environ. Entomol. 38, 985-995.

Rosa García, R., Ocharan, F.J., García, U., Osoro, K., Celaya, R., 2010a. Arthropod fauna on grassland-heathland associations under different grazing managements with domestic ruminants. C. R. Biol. 333 , 226-234.

Rosa García, R., Ocharan, F.J., García, U., Osoro, K., Celaya, R., 2010b. Ground-dwelling arthropod communities present in three types of Cantabrian (NW Spain) heathland grazed by sheep or goats. Eur. J. Entomol. 107, 219-227.

Rosegrant, M.W., Fernandez, M., Sinha, A., Alder, J., de Fraiture, C., Eickhout, B., Fonseca, J., Huang, J., Koyama, O., Pingali, P., Ringler, C., Robinson, S., Thornton, P., van Vuuren, D., Ahammad, H., 2009. Looking into the future for agriculture and AKST. In: McIntyre, B.D., Herren, H.R., Wakhungu, J., Watson, R.T. (Eds.), Agriculture at a Crossroads. Island Press, Washington, DC, pp. 307-376.

Ruiz Mirazo, J., Robles, A.B., González-Rebollar, J.L., 2009. Pastoralism in natural parks of Andalusia (Spain): a tool for fire prevention and the naturalization of ecosystems. Opt. Méd. A 91, 141-144.

Sakanoue, S., Kitahara, N., Hayashi, H., 1995. Biological control of Rumex obtusifolius L. by goat grazing. Japan Agric. Res. Q. 29, 39-42.

Schaller, G.B., Gu, B.Y., 1994. Comparative ecology of ungulates in the Aru Basin of northwest Tibet. Nat. Geogr. Res. 10, 266-293.

Schlecht, E., Dickhoefer, U., Gumpertsberger, E., Buerkert, A., 2009. Grazing itineraries and forage selection of goats in the Al Jabal al Akhdar mountain range of northern Oman. J. Arid Environ. 73, 355-363.

Schofield, E.K., 1989. Effects of introduced plants and animals on island vegetation: examples from the Galapagos Archipelago, Ecuador. Conserv. Biol. 3, 227-238.

Schwartz, H.J., 1983. Improved utilization of arid rangelands through multiple species herds. In: Proceedings of the 5th World Conference on Animal Production, 14-19 August 1983, Japanese Society of Zootechnical Science, Tokyo, pp. 625-626.

Shah, K.B., 2003. On the distribution and status of Tibetan argali, Ovis ammon hodgsoni Blyth, 1841 in Nepal. Him. J. Sci. 1, 37-41.

Shand, H., 1997. Human Nature: Agricultural Biodiversity and Farm-Based Food Security. Rural Advancement Foundation International, Canada.

Shrestha, R., Wegge, P., 2008. Wild sheep and livestock in Nepal Trans-Himalaya: coexistence or competition? Environ. Conserv. 35, 125-136.

Shrestha, R., Wegge, P., Koirala, R.A., 2005. Summer diets of wild and domestic ungulates in Nepal Himalaya. J. Zool. 266, 111-119.

Sidahmed, A.E., 1986. Increasing land utilization by small ruminants in developing countries. In: Timon, V.M., Hanrahan, J.P. (Eds.), Small Ruminant Production in the Developing Countries. FAO Animal Production and Health Paper 58, FAO, Rome, pp. 131-144.

Sidahmed, A.E., Morris, J.G., Koong, L.J., Radosevich, S.R., 1981. Contribution of mixtures of three chaparral shrubs to the protein and energy requirements of Spanish goats. J. Anim. Sci. 53, 1391-1400.

Silanikove, N., 2000. The physiological basis of adaptation in goats to harsh environments. Small Rumin. Res. 35, 181-193.

Silanikove, N., Tagari, H., Shkolnik, A., 1993. Comparison of rate passage, fermentation rate and efficiency of digestion of high fiber diet in desert black Bedouin goats as compared to Swiss Saanen goats. Small Rumin. Res. 12, 45-60.

Simmonds, H., Holst, P., Bourke, Ch., 2000. The Palatability, and Potential Toxicity of Australian Weeds to Goats. Rural Industries Research and Development Corporation, Barton, Australia.

Sineiro, G.F., 1982. Aspects of animal systems in hill pastures in Galicia for meat production. Pastos 12,1-39.

Smit, G.N., Aucamp, A., Richter, C.G.F., 1999. Bush encroachment: an approach to understanding and managing the problem. In: Tainton, N.M. (Ed.), Veld Management in Southern Africa. University of Natal Press, Pietermaritzburg, South Africa, pp. 246-260.

Steinfeld, H., Gerber, P., Wassenaar, T., Castel, V., Rosales, M., de Haan, C., 2006. Livestock's Long Shadow: Environmental Issues and Options. FAO, Rome.

Swain, N., 1984. Performance of sheep and goat in semi-arid region under free range grazing management. Ph.D. Thesis. Bidhan Chandra Krishi Vishwa Vidyalaya, Mohanpur, India.

Theuerkauf, J., Rouys, S., 2006. Do Orthoptera need human land use in Central Europe? The role of habitat patch size and linear corridors in the Białowieża Forest, Poland. Biodivers. Conserv. 15, 1497-1508.

Tyser, R.W., Key, C.W., 1988. Spotted knapweed in natural area fescue grasslands: an ecological assessment. Northwest Sci. 62, 151-160.

Ueckert, D.N., 1980. Manipulating range vegetation with prescribed burning. In: White, L.D. (Ed.), Proceedings of the Symposium on Prescribed Range Burning in the Edwards Plateau of Texas. Junction, TX, 23 October 1980. Texas Agricultural Extension Service, College Station, TX, USA, pp. 27-44. 
Valderrábano, J., Torrano, L., 2000. The potential for using goats to control Genista scorpius shrubs in European black pine stands. Forest Ecol. Manage. 126, 377-383.

Wallace, N.M., Leitch, J.A., Leistritz, F.L., 1992. Economic impact of leafy spurge on North Dakota Wildland. Agricultural Economics Report No. 281. Dep. of Agr. Econ., North Dakota State Univ., Fargo, ND, USA.

Ward, D., 2005. Do we understand the causes of bush encroachment in African savannas? Afr. J. Range Forage Sci. 22, 101-105.

Warren, L.E., Ueckert, D.N., Shelton, J.M., 1984. Comparative diets of Rambouillet, Barbado, and Karakul sheep and Spanish and Angora goats. J. Range Manage. 37, 172-180.

Williams, S., Prather, T., 2006. Goats: A Tool for Controlling Spotted Knapweed (accessed 18.03.11) http://www.joe.org/ joe/2006october/rb6.php.
Wilson, R.T., 1991. Small ruminant production and the small ruminant genetic resource in tropical Africa. FAO Animal Production and Health paper 88. FAO, Rome.

Yoshihara, Y., Ito, T.Y., Lhagvasuren, B., Takatsuki, S., 2008. A comparison of food resources used by Mongolian gazelles and sympatric livestock in three areas in Mongolia. J. Arid Environ. 72, 48-55.

Young, T.P., Palmer, T.M., Gadd, M.E., 2005. Competition and compensation among cattle, zebras, and elephants in a semi-arid savanna in Laikipia, Kenya. Biol. Conserv. 122, 351-359.

Zamora, R., Hódar, J.A., Castro, J., García, D., 2001. Effect of browsing by ungulates on sapling growth of Scots pine in a Mediterranean environment: consequences for forest regeneration. Forest Ecol. Manage. $144,33-42$. 